J. Clin. Chem. Clin. Biochem.

Vol. 25, 1987, pp. 595-600

(C) 1987 Walter de Gruyter \& Co. Berlin - New York

\title{
Specificity of the Amidase and Kininogenase Methods for the Determination of Rat Urinary Kallikrein
}

\author{
By Viviana M. Berthoud and Jenny L. Corthorn \\ Laboratorio de Fisiología, Facultad de Ciencias Biológicas Pontificia Universidad Católica de Chile
}

(Received May 20, 1986/February 9, 1987)

\begin{abstract}
Summary: The specificity of the amidase and kininogenase methods for determining rat urinary kallikrein was studied. Male and female rat urine was employed. Esterase $A_{1}, A_{2}$ and kallikrein were separated by DEAE-Sephadex A-50 chromatography. Esterase $A_{1}$ showed no amidase activity towards the substrate $H-D$ Val-Leu-Arg-p-nitroanilide. In contrast, esterase $A_{2}$ and kallikrein attacked the substrate, and the activity of kallikrein was especially inhibited by aprotinin, while esterase $A_{2}$ was more sensitive to soybean trypsin inhibitor. Esterase $A_{1}$ did not show kininogenase activity, whereas esterase $A_{2}$ showed this activity, but only towards the dog plasma substrate. Kallikrein possessed kininogenase activity towards both dog and rat plasma kininogen. We believe that the most specific method for measuring rat urinary kallikrein activity is the kininogenase method using partially purified rat plasma kininogen.
\end{abstract}

\section{Introduction}

The determination of rat urinary kallikrein $\left.{ }^{1}\right),{ }^{2}$ ) has been used as an index of activity in the renal kallikrein-kinin system. The activity of this enzyme has been measured by bioassay in the rat isolated uterus $(1,2)$, by its esterase activity upon synthetic arginine esters (3) and by its kininogenase activity towards heated plasma or purified fractions from bovine, dog or rat plasma $(4,5)$. More recently, with the availability of synthetic substrates, in which a specific amino acid sequence is coupled to a chromophore (6), the amidase method gained favour, because it was quicker and easier to apply. However, three esterase activities have been described in rat urine: esterase $A_{1}$, esterase $A_{2}$, and kallikrein (7). It has been reported that esterase $A_{2}$, a plasminogen activator, also has kininogenase activity $(7,8)$.

\footnotetext{
1) Abbreviations

KIU: Kallikrein inhibitor units. S-2266: H-D-Val-Leu-Argp-nitroanilide. TAME: $p$-tosyl- $L$-arginine methyl ester $\mathrm{HCl}$. TPCK: $L$-1-toxylamide-2-phenylethyl chloromethyl ketone.

2) Enzymes

Trypsin (EC 3.4.21.4). Tissue kallikrein (EC 3.4.21.35).
}

The purpose of this work was to evaluate the specificity of the amidase method using the substrate $H-D$ Val-Leu-Arg-p-nitroanilide (S-2266), and that of the kininogenase method using partially purified kininogen from dog and rat plasma.

\section{Materials and Methods}

Chemicals

The following materials were obtained from commercial sources: Lima bean trypsin inhibitor (type II-L), Soybean trypsin inhibitor (type II-S), human $\alpha_{1}$-proteinase inhibitor (" $\alpha_{1}$ antitrypsin"), aprotinin, trypsin (type XIII: TPCK ${ }^{1}$ ) treated) and bradykinin (Sigma); S-2266 (Kabi Vitrum, Stockholm, Sweden); DEAE-Sephadex A-50 (Pharmacia Fine Chemicals); $\mathrm{N}^{\alpha}$-p-tosyl-arginine methyl ester (Schwarz Mann); bradykinin antibody was a gift from Dr. O. Carretero, Henry Ford Hospital, Detroit.

\section{Experimental procedure}

\section{Collection of rat urine}

Sprague-Dawley male and female rats were employed. Urine was collected under toluene over $24 \mathrm{~h}$. The urine was filtered and dialysed against distilled water for $48 \mathrm{~h}$, then lyophilized. 
The sample of lyophilized urinc was resuspended at one tenth of the initial volume in $0.01 \mathrm{~mol} / \mathrm{l}$ sodium phosphate buffer $\mathrm{pH}$ 7.0, $0.05 \mathrm{~mol} / / \mathrm{NaCl}$.

\section{Chromatographic separation of esterases}

A. Concentrated urine $(10 \mathrm{ml})$ from male or female rats was applied to a DEAE-Sephadex A-50 column $(0.6 \times 20.0 \mathrm{~cm})$ according to Mc Partland et al. (7). The eluate was collected in three pools: tubes 1 to 10,11 to 20 and 21 to 30 , corresponding to esterases $A_{1}, A_{2}$ and kallikrein, respeclively. These pools were dialysed against $0.01 \mathrm{~mol} / \mathrm{l}$ Tris $\mathrm{HCl}$ buffer $\mathrm{pH} 7.0$ for $24 \mathrm{~h}$. Esterase and amidase activities were then determined in each pool, and the recovery was calculated.

B. Concentrated male rat urine $(60 \mathrm{ml})$ was applied to a DEAESephadex A-50 column $(2.2 \times 12.1 \mathrm{~cm})$ equilibrated in 0.01 mol/l sodium phosphate buffer $\mathrm{pH} 7.0,0.05 \mathrm{~mol} / 1 \mathrm{NaCl}$. The sample was applied and the column, which was then washed with $90 \mathrm{ml}$ of the equilibration buffer, followed by a $500 \mathrm{ml}$ gradient of $0.01 \mathrm{~mol} / 1$ phosphate buffer $\mathrm{pH} 7.0$ from $0.05 \mathrm{~mol} / 1 \mathrm{NaCl}$ to $0.6 \mathrm{~mol} / \mathrm{l} \mathrm{NaCl}$, with a flow rate of $35 \mathrm{ml} / \mathrm{h}$. Three pools of eluted fractions were made: tubes 5 to 19 were considered for esterase $A_{1}$, tubes 32 to 51 for esterase $A_{2}$, and tubes 75 to 103 for kallikrein. These pools were dialysed against distilled water for $24 \mathrm{~h}$ before determining their enzymatic activities, which were used to calculate the recovery.

\section{Analytical Methods}

\section{Esterase activity}

The TAME ${ }^{1}$ ) colorimetric assay (substrate: $\mathrm{N}^{\alpha}$-p-tosyl-arginine methyl ester) employed by Nustad \& Pierce was applied (9). Activity was expressed as $\mu \mathrm{mol}$ of substrate consumed per minute of incubation and per liter of the eluate $(\mathrm{U} / \mathrm{l})$.

\section{Amidase activity'}

The method described by Amundsen et al. (10) was used. Aliquots of urine or of the eluate from the column were incubated with $0.1 \mu \mathrm{mol} H-D$-Val-Leu-Arg-p-nitroanilide (S-2266) for 30 $\mathrm{min}$ in $0.2 \mathrm{~mol} / 1$ Tris- $\mathrm{HCl}$ buffer $\mathrm{pH} 8.0$, final volume of $1 \mathrm{ml}$, in the absence of aprotinin. The reaction was stopped with 0.1 $\mathrm{ml} \mathrm{50 \%} \mathrm{acetic} \mathrm{acid} \mathrm{and} \mathrm{the} \mathrm{absorbance} \mathrm{was} \mathrm{read} \mathrm{at} 405 \mathrm{~nm}$. The activity was expressed in $\mu \mathrm{mol}$ of $p$-nitroaniline $\left(\varepsilon_{40 \mathrm{~s}}=1050 \mathrm{~m}^{2} /\right.$ $\mathrm{mol}$ ) formed in one min of incubation per liter of the eluate or urine $(\mathrm{U} / \mathrm{l})$.

\section{Inhibition studies}

Aliquots of the $\mathrm{A}_{2}$ esterase pool, with an amidase activity of $0.58 \pm 0.02 \mathrm{nmol} / \mathrm{min}$ and of the kallikrein pool with an amidase activity of $0.54 \pm 0.02 \mathrm{nmol} / \mathrm{min}$ were incubated with soybean trypsin inhibitor or Lima bean trypsin inhibitor (final concentration 2.5 to $50 \mathrm{mg} / \mathrm{l}$ ), aprotinin (final concentration 25 to $500 \mathrm{KIU} / \mathrm{ml}$ ), or $\alpha_{1}$-proteinase inhibitor (final concentration 0.5 to $50 \mathrm{mg} / \mathrm{l}$ ) for $30 \mathrm{~min}$ at $37^{\circ} \mathrm{C}$ in $0.2 \mathrm{~mol} / \mathrm{l} \mathrm{Tris}-\mathrm{HCl}$ buffer $\mathrm{pH} 8.0$, final volume $0.9 \mathrm{ml}$. The substrate $\mathrm{S}-2266^{1}$ ) was then added and the amidase method was resumed.

\section{Kininogenase activity}

A modification of the method described by Carretero et al. (11) was used. One aliquot of the enzyme was incubated with kininogen (capable of generating $500 \mathrm{ng}$ kinins) in $0.05 \mathrm{~mol} / \mathrm{l}$ sodium phosphate buffer $\mathrm{pH} 7.4,0.15 \mathrm{~mol} / \mathrm{l} \mathrm{NaCl}, 3 \mathrm{mmol} / \mathrm{l}$ EDTA, $1 \mathrm{mmol} / 1$ o-phenanthroline, $250 \mathrm{mg} / 1 \mathrm{NaN}_{3}$, in a final volume of $0.5 \mathrm{ml}$ for $15 \mathrm{~min}$. The reaction was stopped with $2 \mathrm{ml} 960 \mathrm{~g} / \mathrm{l}$ ethanol. The precipitate was washed with $1 \mathrm{ml} 960$ $\mathrm{g} / \mathrm{l}$ ethanol. The supernatants containing the kinins were dried in a bath at $50^{\circ} \mathrm{C}$ under a stream of air. The residue obtained

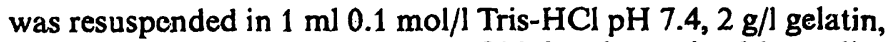
$250 \mathrm{mg} / 1 \mathrm{NaN}_{3}$ and the amount of kinins determined by radioimmunoassay. Enzymatic activity was expressed as mg of kinins produced per minute of incubation per liter of the eluate $(\mathrm{mg} /$ $\min \cdot 1)$.

\section{Kininogen preparation}

The citrated plasma from rat or dog blood was heated to $56^{\circ} \mathrm{C}-60^{\circ} \mathrm{C}$ for 3 hours, followed by addition of solid ammonium sulphate $(114 \mathrm{~g} / \mathrm{l})$ to 0.25 saturation. The mixture was stirred for one hour at room temperature, then centrifuged at $12100 \mathrm{~g}$ for $10 \mathrm{~min}$; the supernatant was again precipitated with ammonium sulphate $(125 \mathrm{~g} / \mathrm{l})$ at 0.43 saturation. The precipitate was resuspended and dialysed against distilled water at $4{ }^{\circ} \mathrm{C}$ for $48 \mathrm{~h}$. It was then submitted to a chromatographic separation on DEAE-Sephadex A-50, previously equilibrated with $0.02 \mathrm{~mol} / \mathrm{l}$ phosphate buffer $\mathrm{pH} 6.3,0.05 \mathrm{~mol} / 1 \mathrm{NaCl}$. The fraction containing kininogen was eluted with a linear gradient ranging from $0.05 \mathrm{~mol} / 1$ to $0.5 \mathrm{~mol} / 1 \mathrm{NaCl}$. It was finally dialysed and lyophilized. The kininogen content was estimated by incubation with an excess of trypsin or rat urinary kallikrein. The kinin content of dog kininogen per mg protein was 1400 ng with trypsin and $1152 \mathrm{ng}$ with kallikrein, while the kinin content of rat kininogen was $409 \mathrm{ng}$ with trypsin and $126 \mathrm{ng}$ with kallikrein. Heated rat plasma and the kininogen preparations did not show kininase activity when incubated under the conditions of the kininogenase assay.

\section{Radioimmunoassay for kinins}

Briefly, the samples or standards were incubated in $0.1 \mathrm{~mol} / \mathrm{l}$ Tris- $\mathrm{HCl} \mathrm{pH} 7.4,2 \mathrm{~g} / \mathrm{l}$ gelatin, $250 \mathrm{mg} / \mathrm{l}$ sodium azide with bradykinin antiserum $\left(1: 40000\right.$ and $\left[{ }^{125}\right.$ I]bradykinin $(10000$ counts/min) in a final volume of $0.6 \mathrm{ml}$ at $4{ }^{\circ} \mathrm{C}$ for $20 \mathrm{~h}$. One $\mathrm{ml}$ of dextran coated charcoal in barbital buffer $\mathrm{pH} 7.4$ was then added, and after centrifugation at $4810 \mathrm{~g}$ for $20 \mathrm{~min}$ the supernatant was separated and counted in a Gamma LKB counter. The sensitivity of the RIA was $10 \mathrm{pg}$ with an intraassay variability coefficient of $4.2 \%$ and an interassay variability coefficient of $6.7 \%$.

\section{Protein determination}

Protein was measured by absorbance at $280 \mathrm{~nm}$ and by the method of Lowry et al. Bovine serum albumin was used as standard (12).

\section{Conductivity determination}

The conductivity of DEAE-Sephadex $A=50$ chromatography fractions was measured at $25^{\circ} \mathrm{C}$ with a Radiometer conductivity meter, Copenhagen Type CDM $2 \mathrm{e}$.

\section{Results}

Úsing DEAE-Sephadex chromatography, three peaks of TAME esterase activity were found in the urine of male rats and two peaks in the urine of female rats (fig. $1 \mathrm{a}$ and $1 \mathrm{~b}$ ). The peak that eluted at a concentration of $0.05 \mathrm{~mol} / 1 \mathrm{NaCl}$ was present only in male rats, and did not show any .amidase activity with . 6

J. Clin. Chem. Clin. Biochem. / Vol. 25, 1987 / No. 9 

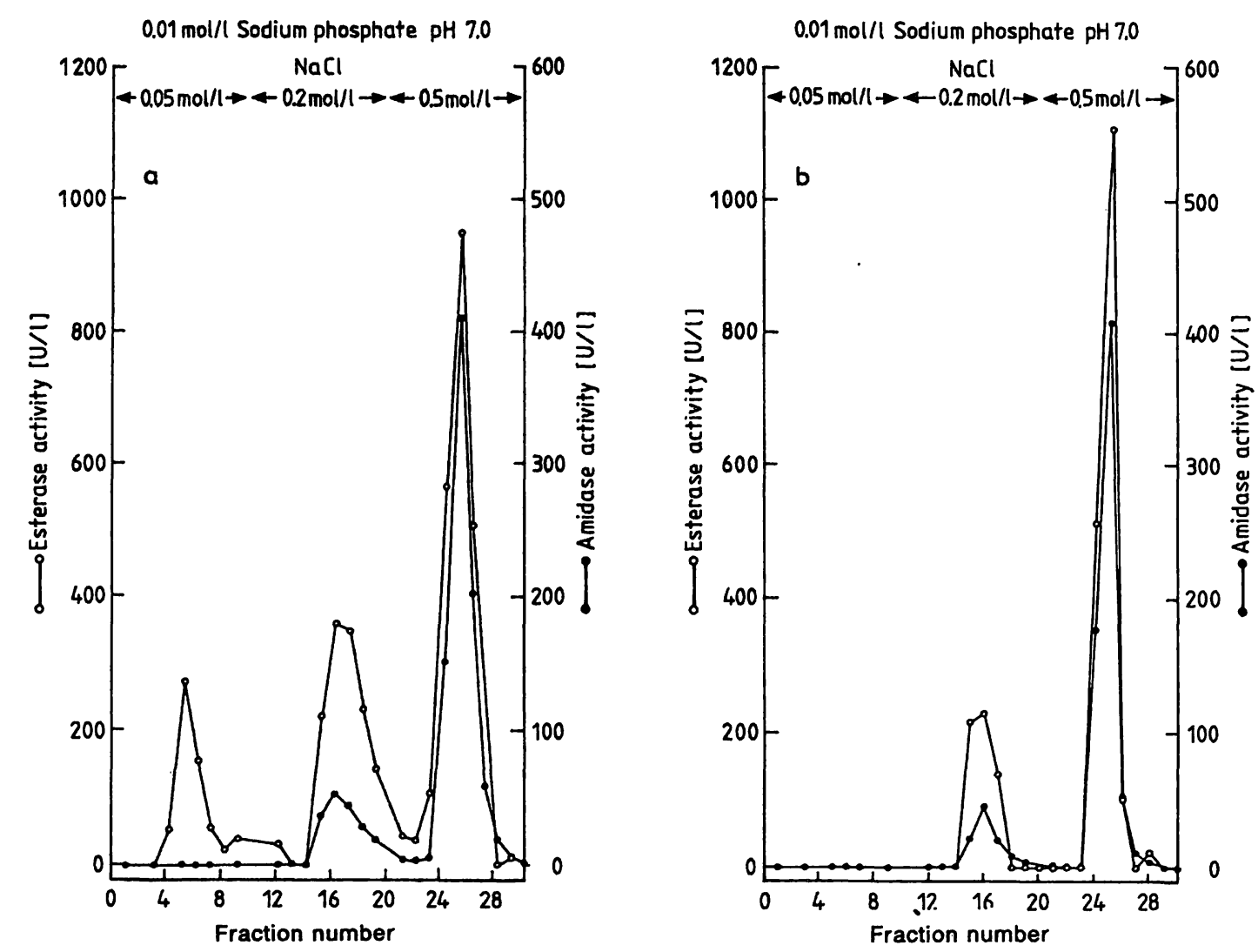

Fig. 1. DEAE-Sephadex A-50 chromatography with stepwise elution of rat urine.

Elution profile of the esterase (substrate: $p$-tosyl- $L$-arginine methyl ester hydrochloride, $0-0$ ) and amidase (substrate: $\mathrm{H}$ - $D$-Val-Leu-Arg-p-nitroanilide, $\bullet-\bullet)$ activities.

(a) male rat urine; the flow rate was $24 \mathrm{ml} / \mathrm{h}$. Fractions $(1 \mathrm{ml})$ were collected, and fractions 1 to 10,11 to 20 and 21 to 30 were pooled.

(b) female rat urine; the flow rate was $9 \mathrm{ml} / \mathrm{h}$; fractions were collected and pooled as for male rat urine.

$D$-Val-Leu-Arg-p-nitroanilide. In contrast, the peaks that eluted at concentrations of $0.2 \mathrm{~mol} / 1$ and 0.5 $\mathrm{mol} / 1 \mathrm{NaCl}$, corresponding to esterase $\mathrm{A}_{2}$ and kallikrein, did contain amidase activity from both male and female rats. The peak of esterase $A_{2}$ accounted for $16.9 \%$ of the total amidase activity present in the urine of male rats and for $14.8 \%$ of that present in female rats.

We believe that the esterase $A_{2}$ fraction is free from renal kallikrein, since the results from chromatography with stepwise elution were confirmed by a gradient elution procedure, which gave better resolution. Repetition of this procedure showed that the esterase $A_{2}$ fraction.always showed kininogenase activity (see fig. 4). We submitted the esterase $A_{2}$ fraction to Western blot analysis with polyclonal antibody against rat urinary kallikrein, and the results were negative. It has been reported that highly purified esterase. $A_{2}$ shows kininogenase activity towards heated dog plasma $(8,14)$.

The recovery of amidase activity was $\mathbf{9 2 . 7 \%}$ for male rat urine and $72.9 \%$ for female rat urine.
The pattern of inhibition of these amidase activities was studied against some trypsin inhibitors in order to selectively inhibit one of the two enzymes. The amidase activity of esterase $A_{2}$ proved to be more sensitive than that of kallikrein to soybean trypsin inhibitor (fig. 2); on the other hand, the latter was more sensitive than esterase $A_{2}$ to aprotinin (fig. 3). However, none of these inhibitors is specific for any of these enzymes. In fact, soybean trypsin inhibitor at $50 \mathrm{mg} / \mathrm{l}$, which inhibited $85.9 \%$ of the esterase $\mathrm{A}_{2}$ activity, also inhibited kallikrein up to $12.3 \%$. Likewise, aprotinin concentrations $(50,100$ and 200 $\mathrm{KIU} / \mathrm{ml}$ ) that inhibited kallikrein up to $95.8 \%, 98.8 \%$ and $99.5 \%$, respectively, also inhibited esterase $A_{2}$ up to $30 \%, 43.5 \%$ and $61 \%$. Lima bean trypsin inhibitor and $\alpha_{1}$-antiproteinase did not inhibit the amidase activity either of esterase $A_{2}$ or of kallikrein at the concentrations employed.

The study of the ability of the fractions containing esterase $A_{1}, A_{2}$ and kallikrein to generate kinins from kininogen from dog or rat plasma was carried out in urine from male rats. This urine was submitted to 


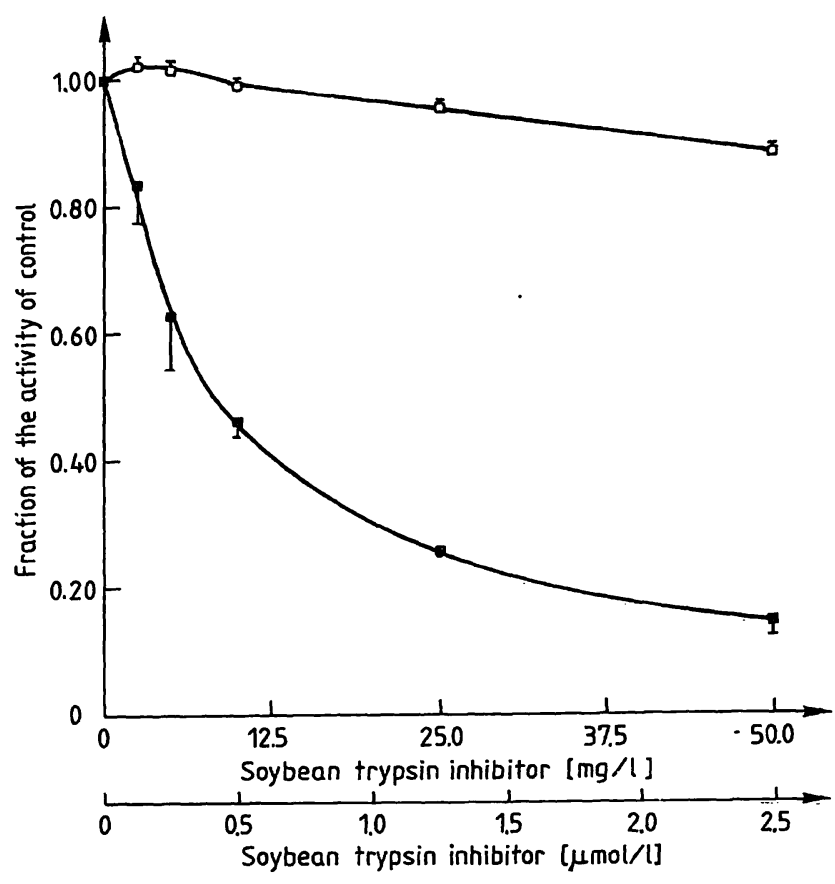

Fig. 2. Inhibition of the two amidase activities (substrate: $H-D$ Val-Leu-Arg-p-nitroanilide) present in rat urine by soybean trypsin inhibitor.

Aliquots of esterase $A_{2}$ fraction ( $\square$ ) with an amidase activity of $0.58 \pm 0.02 \mathrm{nmol} / \mathrm{min}$ and of kallikrein fraction (ם) with an amidase activity of $0.54 \pm 0.02 \mathrm{nmol} /$ min were incubated with increasing concentration of soybean trypsin inhibitor (as described in Materials and Methods). Values are expressed as $\bar{x} \pm S$. D. of three determinations.

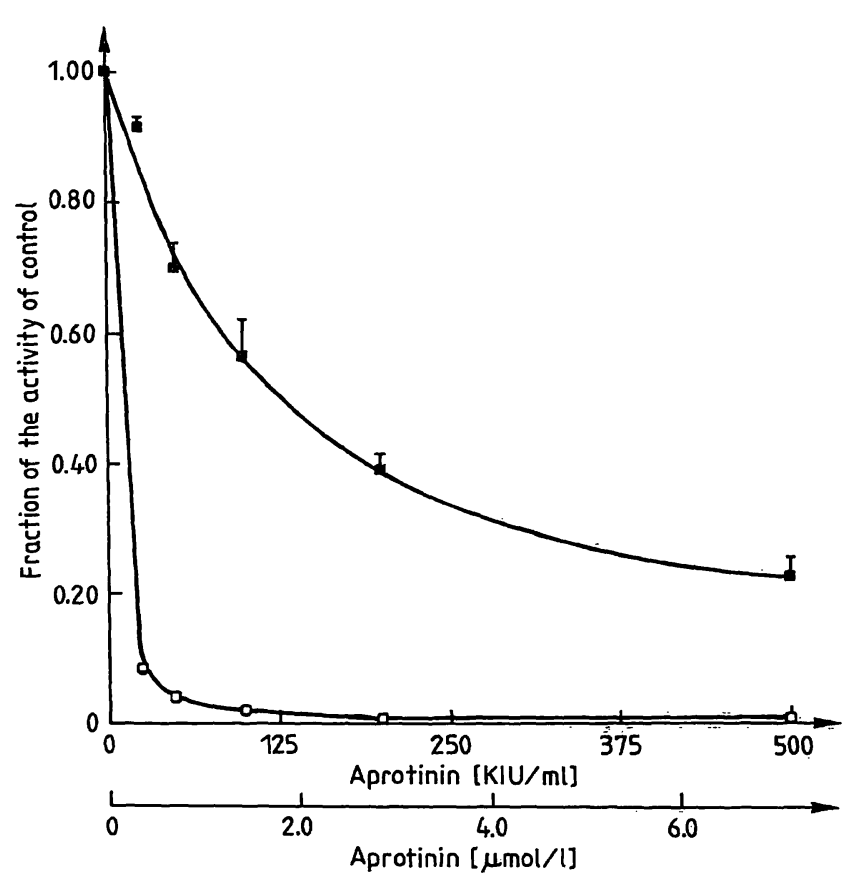

Fig. 3. Inhibition of the two amidase activities present in rat urine by aprotinin.

The conditions were the same as those described in the legend to figure 2, except that aprotinin was used instead of soybean trypsin inhibitor. (a) esterase $A_{2}$ fraction; (ㅁ) kallikrein fraction. Values are expressed as $\overline{\mathrm{x}} \pm$ S.D. of three determinations. chromatographic separation with a gradient elution in order to better resolve the peaks of enzymatic activity. It was found that the first peak of esterase activity had no kininogenase activity. However, the two peaks of esterase activities, which also possessed amidase activity, also hydrolysed dog kininogen. In contrast, rat kininogen from heated plasma, or the partially purified fraction of kininogen, was hydrolysed only by kallikrein (fig. 4). The ratios of kininogenase activity/amidase activity when using the dog
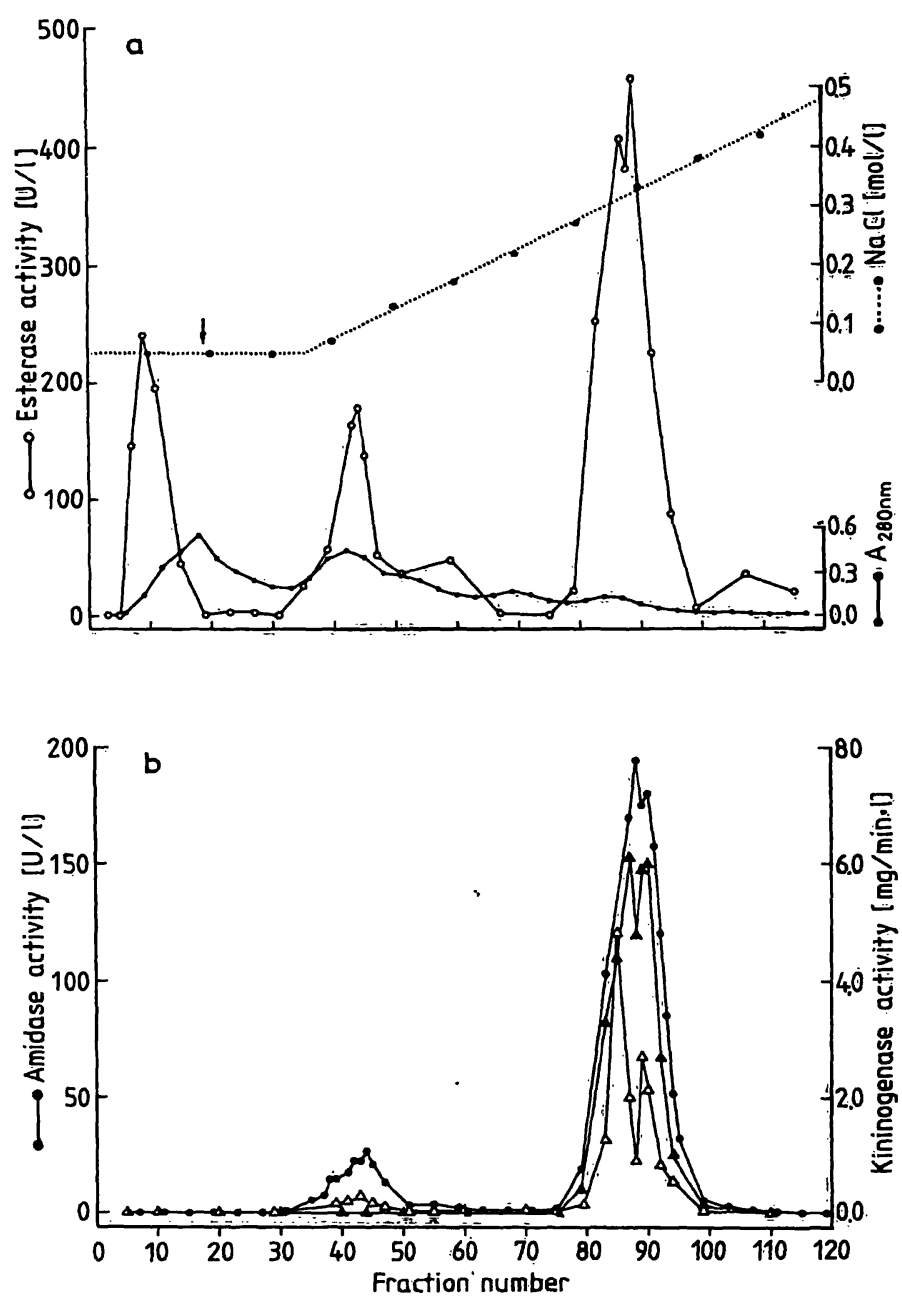

Fig. 4. Chromatography of male rat urine in DEAE-Sephadex A-50 with gradient elution.

The flow rate was $35 \mathrm{ml} / \mathrm{h}$ and $5 \mathrm{ml}$ fractions were collected. The arrow indicates the beginning of the elution gradient from $0.05 \mathrm{~mol} / 1 \mathrm{NaCl}$ to $0.5 \mathrm{~mol} / 1 \mathrm{NaCl}$ in $0.01 \mathrm{~mol} / 1$ sodium phosphate buffer $\mathrm{pH} \overline{7} .0$.

a) Plot of $\mathrm{A}_{280}(-\bullet), \mathrm{NaCl}$ concentrations $(\bullet \cdots \bullet)$ and esterase activity (substrate: $p$-tosyl- $L$-arginine methyl ester hydrochloride, $0=0$ ). $\mathrm{NaCl}$ concentration in the eluate was estimated from conductivity measurements. b) Plot of amidase activity (substrate: H-D-Val-LeuArg-p-nitroanilide, - - and kininogenase activity towards dog kininogen $(\triangle)$ and towards rat kininogen $(\mathbf{A})$.

Fractions pooled were: $5-19$ for esterase $A_{1} ; 32-51$ for esterase $A_{2}$; and $75-103$ for kallikrein.

J. Clin. Chem. Clin. Biochem. / Vol. 25, 1987 / No. 9 
substrate were 0.026 and 0.027 (kinin, $\mathrm{mg} / \mathrm{min} \cdot \mathrm{l}) /(p$ nitroaniline, $\mu \mathrm{mol} / \mathrm{min} \cdot 1$ ) for esterase $A_{2}$ and kallikrein, respectively, and these values are similar to those found in whole urine $(0.025)$. When using rat kininogen as the substrate, the ratios were 0 and 0.048 , respectively. Neither esterase $A_{2}$ nor kallikrein showed kininase activity. The recovery of amidase activity was $84.3 \%$, while that of kininogenase activity was $68.7 \%$ with dog kininogen, and $67.2 \%$ with rat kininogen.

\section{Discussion}

Three esterase activities were found in the urine of male rats: $A_{1}, A_{2}$ and kallikrein, whereas female rat urine had no esterase $A_{1}$ activity. According to our results, esterase $A_{2}$ showed amidase activity towards the synthetic substrate S-2266. Using this substrate, it was shown that esterase $A_{2}$ accounted for about $15 \%$ of the total amidase activity present in the urine of both male and female rats. This value was similar to that described by Takaoka et al. in Wistar rat urine when using the synthetic substrate Pro-Phe-Arg-4methylcoumaryl-7-amide (13).

The study of the inhibition of the two amidase activities present in urine revealed that esterase $A_{2}$ was inhibited more by soybean trypsin inhibitor than by aprotinin, whereas kallikrein was more inhibited by aprotinin than by soybean trypsin inhibitor. Moreover, using similar initial activities of esterase $A_{2}$ and kallikrein, soybean trypsin inhibitor inhibited esterase $\mathrm{A}_{2}$ more than kallikrein at the same concentrations of the inhibitor, whereas aprotinin inhibited the latter more than esterase $\mathrm{A}_{2}$. These results are fully consistent with those described by Nustad \& Pierce (9) for the esterase activity of these enzymes. Nonetheless, in contrast with our results, McPartland et al. found that the arginine esterase activity of esterase $A_{2}$ is more inhibited by aprotinin than by soybean trypsin inhibitor (14). On the other hand, Morimoto et al. found that the amidase activity of esterase $A_{2}$ with Pro-Phe-Arg-4-methylcoumaryl-7-amide is more inhibited by soybean trypsin inhibitor than that of kallikrein, which agrees with the data presented here. However, their results on aprotinin are at variance with ours, since they found that both enzymes are inhibited to a similar extent by this inhibitor (15). These discrepancies are possibly due to the different substrate used to determine enzymatic activity and to the degree of purity of the enżymatic fractions employed, since the presence of other proteins can modify the sensitivity of the enzyme to the inhibitors. (14).
It must be emphasized that in our experiments, in which similar activities of esterase $A_{2}$ and kallikrein were incubated with increasing amounts of aprotinin, we observed that an aprotinin concentration of 50 $\mathrm{KIU} / \mathrm{ml}$ inhibited kallikrein by $95.9 \%$ and left a remnant esterase $A_{2}$ activity of $70 \%$. On the light of these findings, the specificity of the amidase method published by Amundsen et al. (10) for the determination of rat urinary kallikrein seems to be highly questionable. It is doubtful whether this method is selective for this enzyme if the sample is read against a blank in the presence of $10 \mathrm{KIU}$ or $50 \mathrm{KIU}$ aprotinin $(10,16,17)$.

On the other hand, esterase $A_{2}$, as well as kallikrein, were able to release kinins from partially purified dog kininogen, which is in agreement with the findings of McPartland et al. (7, 14), Nustad \& Pierce (9), Chao et al. (8) and Morimoto et al. (15). Both urine and the isolated fractions of esterase $A_{2}$ and kallikrein showed the same ratio kininogenase activity/amidase activity. It is then reasonable to assume a good correlation between the kininogenase method using dog substrate and the amidase method described by Amundsen et al. (10), an argument that has been used to validate the determination of urinary kallikrein by the amidase method (17). This implies that the kininogenase method using substrate from dog plasma is as unspecific as the amidase method for the determination of rat urinary kallikrein activity.

Obviously, the most important finding reported here is that esterase $A_{2}$ was unable to release kinins from heated rat plasma and from partially purified rat kininogen. These results agree with those of McPartland et al. (7) and Nustad \& Pierce (9) who did not observe any change in the pressor test in the rat when injecting the $A_{2}$ fraction. This different behaviour of esterase $A_{2}$ towards the dog and rat substrates might be due to the specificity of the substrate. However, we cannot rule out the existence of an inhibitor in the preparation of rat kininogen that may fully inhibit fraction $A_{2}$. Studies are in progress to help elucidate this point.

The determination of rat urinary kallikrein activity may be rendered selective by using either the amidase or kininogenase assay on dog kininogen applied to urine previously subjected to a chromatographic separation (18).

\section{Acknowledgements}

This work was supported by Grants $1187 / 84$ Comisión Nacional de Investigación Científica y Tecnológica (CONICYT) and 80/85 from Dirección de Investigación de la Pontificia Universidad Católica de Chile. 


\section{References}

1. Beraldo, W. T., Araujo, R. L. \& Mares-Guia, M. (1966) Am. J. Physiol. 211, 975-980.

2. Croxatto, H. R. \& San Martín, M. (1970) Experientia 26, 1216-1217.

3. Beaven, V. H., Pierce, J. V. \& Pisano, J. J. (1971) Clin. Chim. Acta 32, 67-73.

4. Nustad, K. (1970) Br. J. Pharmac. 39, 73-86.

5. Shimamoto, K., Ando, T., Nakao, T., Tanaka, S., Sakuma, M. \& Miyahara, M. (1978) J. Lab. Clin. Med. 91, 721 728.

6. Cleaeson, G., Aurell, L., Friberger, P., Gustavsson, S. \& Karlsson, G. (1978) Haemostasis 7, 62-68.

7. McPartland, R. P., Sustarsic, D. L. \& Rapp, J. P. (1981) Endocrinology 108, 1634-1638.

8. Chao, J. (1983) J. Biol. Chem. 258, 4434-4439.

9. Nustad, K. \& Pierce, J. (1974) Biochemistry 13, 23122319.

10. Amundsen, E., Putter, J., Friberger, P., Knos, M., Larsbraten, M. \& Claeson, G. (1979) in Advances in Experimental Medicine and Biology, Kinin II, 120 A (Fujii, S., Moriya, H. \& Suzuki, T., eds) pp. 83-95, Plenum Press, New York.

11. Carretero, O., Oza, N., Piwonka, A., Ocholik, T. \& Scicli, A. (1976) Biochem. Pharmacol. 25, 2265-2270.

12. Lowry, O. H., Rosebrough, N. J., Farr, A. L. \& Randall, R. J. (1951) J. Biol. Chem. 193, 265-275.

13. Takaoka, M., Ariyama, H., Okamura, H. \& Morimoto, S. (1984) Chem. Pharm. Bull. 32, 1120-1125.

14. McPartland, R. P., Rapp, J. P., Joseph, M. K. \& Sustarsic, D. L. (1983) Biochim. Biophys. Acta 742, 100-108.

15. Morimoto, S., Nakajima, M., Mizunoya, Y., Okamura, $H$., Akiyama, H. \& Takaoka, M. (1984) Chem. Pharm. Bull. 32, 4572-4579.

16. Camps, J., Costa, J., Pérez-Aỹuso, R. M., Rimola, A., Arroyo, V. \& Gaya, J. (1983) Revista Española de Fisiología 39, 255-230.

17. Bönner, G. \& Marin-Grez, M. (1981) J. Clin. Chem. Clin. Biochem. 19, 165-168.

18. Funae, Y., Akiyama, H. \& Imaoka, S. (1983) J. Chromatogr. $264,249-257$.

Jenny Corthorn Laboratorio de Fisiología

Departamento de Ciencias Fisiológicas

Facultad de Ciencias Biológicas

P. Universidad Católica de Chile

Casilla 114-D

Santiago - Chile 